\title{
Influence of Entrepreneurial Orientation on Firm Performance of Kenya's Agro Processing Small and Medium Enterprises
}

\author{
Angeline Wambui Wambugu ${ }^{1,}$ Prof. Robert Gichira ${ }^{2,}$ Dr. Kenneth Wanjau ${ }^{3}$ \\ ${ }^{1}$ Jomo Kenyatta University of Agriculture and Technology, Kenya P.O. Box 25626-00100 Nairobi \\ ${ }^{2}$ School of Entrepreneurship, Procurement and Management, Jomo Kenyatta University of Agriculture And \\ Technology, P. O. Box 62000-00200, Nairobi, Kenya \\ ${ }^{3}$ School of Business, Karatina University, Kenya
}

\begin{abstract}
The study used Structural Equation Modeling partial least squares (SEM-PLS)to investigate the influence of Entrepreneurial Orientation on Firm Performance of Kenya's Agro Processing SMEs. The study was undertaken on Agro Processing SMEs registered with Kenya Association of Manufacturers operating with Nairobi and its environs. The questionnaires were self-administered on owner/managers of agro processing SMEs. Entrepreneurial Orientation was conceptualized and analyzed as a latent second-order construct comprised of innovativeness, proactiveness and risk taking. The study results revealed that Entrepreneurial Orientation has a positive and statistically significant influence on firm performanceof Kenya's agro processing SMEs. The study concludedthat Entrepreneurial Orientation as a uni-dimensional construct is an important predictor of firm performance, in terms of growth and profitability. The implication of this finding for managerial practice and future research is discussed.
\end{abstract}

Keywords:-Entrepreneurial Orientation, Firm Performance, Agro Processing, Small and Medium Enterprises, Kenya.

\section{Introduction}

Agro processing is a crucial social economic activity given that Kenyais a largely agricultural based economy. Vision 2030 recognizes that there is a mutually reinforcing relationship between agriculture and manufacturing industry. Thus, the policy framework focuses on strengthening local production capacity of agro processing firms (Republic of Kenya, 2007). TheAgro Processing industry has the largest number of formally registered enterprises of the entire number of manufacturing firms and is dominated by small and medium enterprises (Kormawa, Wohlmuth \& Devlin, 2011). Agro processing small and medium enterprises (SMEs) are critical in accelerating economic growth through employment generation, farm and off-farm income, value addition, regional industrial performance and distribution of local and material resources (Republic of Kenya, 2007). Yet agro processing SMEs are characterized by limited technological capacity, low product diversification, lack of flourishing entrepreneurship activities and low value addition (Republic of Kenya, 2008). Kenya's agro processing SMEsneed dynamic capabilities that will enable them to generate important employment and poverty reduction effects, increase local production capacity and enhance firm performance. Awang, Ahmad, Asghar, Subari and Kassim (2011) propose that high entrepreneurial orientation is positively related to successful entrepreneurial outcomes, higher human capital, tacit knowledge and efficient technology utilization of agro based SMEs. Entrepreneurial orientation plays an important role in enhancing firm performance of SMEs in terms of profitability, sales and employee growth (Keh, Nguyen \& $\mathrm{Ng}$, 2007). The objective of the study therefore, is to investigate the influence of Entrepreneurial Orientation onFirm Performance of Kenya's agro processing SMEs. The hypothesis for the study is: -There is no relationship between entrepreneurial orientation and firm performance of Kenya's agro processing SMEs.

\subsection{Entrepreneurial Orientation Theory}

\section{Literature Review}

Entrepreneurial orientation (EO) is conceptualized as a firm level strategy making process that firms use to enact their organizational purpose, sustain their vision and create competitive advantage (Wiklund \& Shepherd, 2003). Entrepreneurial orientation reflects the organizational processes, practices, methods, and decision-making styles that owners/managers use to act entrepreneurially (Lumpkin \& Dess, 1996; Stevenson \& Jarillo, 1990; Li, Huang \& Tsai, 2009).Miller (1983) suggests that firm-level entrepreneurship is associated with renewal of the organization and encompasses product-market innovation, proactiveness, and risk taking. Lumpkin and Dess (1996) propose that entrepreneurial orientation consist of five factors namely risk taking, proactiveness, innovativeness, competitive aggressiveness and autonomy. These five dimensions of entrepreneurial orientation vary independently with each other depending on the environmental and organizational context (Dess \& Lumpkin, 2005; Kreiser, Marion \& Weaver, 2002). Covin, Green and Slevin 
(2006), however, argue that it is the combined influence of entrepreneurial orientation dimensions that makes a firm to act entrepreneurially. Thus,it is the firm's ability to adopt innovative, proactive and risk-seeking strategies that leads to achievement of performance objectives (Venkatraman, 1989).Innovativeness dimension of entrepreneurial orientation refers to attempts to embrace creativity, experimentation, novelty, technological processes that results in the introduction of new products (Lyons, Lumpkin \& Dess, 2001). Risk taking reflects a firm's readiness to commit resources in uncertain environments, exploring new segments and devoting increased resources to projects whose outcome is difficult to predict (Tajeddini, 2010). Proactiveness refers to the process of anticipating and acting on future needs by seeking new opportunities, introduction of new products and brands ahead of competition, strategically eliminating operations which are in the mature or declining stages of the life cycle (Lumpkin \& Dess, 2001). In this study, entrepreneurial orientation is conceptualized as a uni-dimensional construct comprised of proactiveness, risk taking and innovativeness.

\subsection{Firm Performance Theory}

Firm performance is an important construct in the field of strategic entrepreneurship. Lumpkin and Dess (1996) argue that entrepreneurial activity or process may at times lead to favorable outcomes on one performance dimension and unfavorable outcomes on a different performance dimension. As such, in entrepreneurial orientation studies, it is important to recognize the multi-dimensional nature of the performance construct that combines financial and growth performance measures (Wiklund,1999). Research has shown that combining financial and growth measures give a richer description of the actual performance of the firm (Wiklund, 1999; Lumpkin \& Dess, 1996; Fairoz, Hirobumi \& Tanaka, 2010; Zainol \& Ayadurai, 2011). Financial performance measures are based on traditional measures such as accounting/financial data or market based measures. Accounting data reflect a firm's past financial performance while market based measuresare based on valuation principles (Kaplan \& Norton, 2000). Financial measures are critical in determining the survival of the firm but research studies warn against a heavy reliance on financial measures as they are unstable, easily manipulated and sensitive to changing industry-related factors (Aggarwal \& Gupta, 2006; AlSwidi \& Al-Hosam, 2012).

In measuring firm performance of small and medium enterprises, both subjective and objective measures can be used. Objective measures are obtained from firm's annual accounts or financial records whilesubjective measures involve seeking the perception of owner/managers on overall performance relative to that of competitors during a certain time period (Idar \& Mahmood, 2011). Objective measures are difficult to obtain because owner/managers are generally conservative and unwilling to release actual financial information to outsiders (Chao \& Spillan, 2010; Wang \& Poutziouris, 2010). Thus, the use of subjective measures of firm performance is consistent with empirical studies (Idar \& Mahmood, 2011). The perception of owner/managers has been found to be highly consistent with how firms essentially perform as indicated by objective measures. (Dess \& Robinson,1984). In this study, subjective measures of firm performance were assessed by asking owner/managers of agro processing SMEs to rate their satisfaction with sales growth, employee growth and profitability relative to that of competitors over the past five years.

\subsection{Entrepreneurial Orientation and Firm Performance}

The importance of entrepreneurial orientation and its influence on firm performance has been highlighted in both theoretical discussion and empirical research. Entrepreneurial orientation as a unidimensional construct has been identified as a key ingredient for organizational success (Covin \& Slevin, 1991; Zahra, 1993; Wiklund, 1999; Poon, Ainuddin \& Junit, 2006). Fairoz, Hirobumi and Tanaka (2010) suggest that firms that adopt high entrepreneurial orientation achieve higher sales growth, higher profits and increased market share compared to those with low entrepreneurial orientation. Similarly, Rauch, Wiklund, Lumpkin and Frese (2009) posit that firms that adopt entrepreneurial orientation perform better than firms that adopt a conservative orientation. Previous studies have shown that entrepreneurial orientation has a significant relationship with firm performance of SMEs in terms of sales growth, profitability and overall firm performance.A study by Mahmood and Hanafi (2013) found out that entrepreneurial orientation has a positive effect on business performance of women-based SMEs in Malaysia. Similarly, a study byKeh, Nguyen and Ng (2007) found out that entrepreneurial orientation has a significant influence on firm performance of Singapore small and medium enterprises. A study by Arbaugh, Cox and Camp (2009) using a sample of 1045 firms from 17 countries found out that the uni-dimensional entrepreneurial orientation significantly predicted firm profitability. Otieno, Bwisa and Kihoro (2012) found out that entrepreneurial orientation has a significant influence on firm performance of Kenya's manufacturing firms operating under East African Community regional, in terms of sales, profits and employment. 


\section{Research Methodology}

\subsection{Sampling and Data Collection}

The research study adopted an exploratory research design. The study was undertaken onAgro Processing SMEs registered with Kenya Association of Manufacturers operating with Nairobi and its environs. According to the Kenya Association of Manufacturers, these enterprises have the potential to enhance their firm performance in terms of sales, profits and employment and thereby, to contribute to Kenya's poverty reduction strategy and Vision 2030 (KAM, 2010). The study adopted a census sampling technique.Primary data on entrepreneurial orientation and firm performance was collected over a period of six months by means of a semistructured questionnaire. A total of 111 questionnaires were self-administered on owner/managers of agro processing SMEswho were considered capable of answering the questions knowledgeably and accurately due to their experience and insight about their enterprises and the industry (Lyon, Lumpkin\& Dess, 2000). A total of 97 usable questionnaires were received out of 111 questionnaires.The results revealed a response rate of $87.3 \%$ which was considered to be very good. According to Mugenda (2008), a response rate of 50\% is considered adequate, $60 \%$ and above good, and above $70 \%$ very good.

\subsection{Measures}

The questionnaire was used to measure Entrepreneurial orientation and firm performance of the firm. The questionnaire used a five point Likert scale on which the owner/managers had to indicate the extent to which the items represented their firm's strategywhere $1=$ never and $5=$ always. Mean scales scores were calculated for all measures.Entrepreneurial orientation was measured as a second order construct comprised of proactiveness, risk taking and innovativeness. Firm performance was measured by the asking owner/managersto state their satisfaction with firms' performance for the past five years in comparison with competitors. This variable was also gathered using 5 -point Likert scale where $1=$ not at all satisfied and $5=$ extremely satisfied.

\section{Research Findings And Data Analysis}

\subsection{Characteristics of the Respondents}

The demographic characteristics of the respondents indicate that more than $62.8 \%$ were male, $47 \%$ were between 31 and 40 years, $41.2 \%$ had a bachelor's degree and $38.5 \%$ had worked in the agro processing industry. The results also revealed that $75.2 \%$ of the respondents were limited liability companies, $40 \%$ had been operation for more than 15 year and $72.2 \%$ of the respondents were engaged in agro food processing.

\subsection{Measurement Model Estimation}

The study constructs were initially purified using Exploratory Factor Analysis (EFA). EFA was performed on the items composing the constructs to identify the variables that cluster together into the most effective number of factors (Bordens \& Abbot, 2014) and identify the structure of the measurement model (Hair, Black, Babin \& Anderson, 2010). Prior to performing EFA, the suitability of the data was assessed through two tests, that is, Kaiser-Meyer-Olkin measure of sampling adequacy (KMO) and Bartlett's Test of Sphericity. Kaiser-Meyer-Olkin measure of sampling adequacy (KMO) is a measure to quantify the degree of correlations among the variables which indicates the proportion of variance in the study variables that might be caused by the underlying factors. The KMO index ranges from 0 to 1 , the closer the value to 1 , the more significant the correlation among the variables (Kaiser, 1974; Li, Huang, Wang and Chelliah, 2011). On the other hand, Bartlett's test of Sphericity provides the statistical probability that the correlation matrix has significant correlations among at least some of the variables with small values $(\mathrm{p}<0.5)$ indicating that the data is useful in factor analysis. In this study, the results as illustrated in Table 1 indicated that all variables had achieved KMO index values of 0.600 above the threshold of 0.500 and $p$ values below 0.05 which showed that the correlation was significant. 
Table 1: KMO Measure of Sampling Adequacy and Bartlett's Test of Sphericity

\begin{tabular}{|l|l|l|}
\hline Variable & $\begin{array}{l}\text { KMO Measure of Sampling } \\
\text { Adequacy }\end{array}$ & Bartlett's Test of Sphericity \\
\hline Proactiveness & 0.687 & $\begin{array}{l}\text { Approx. Chi-Square 30.805 } \\
\text { df 6 } \\
\text { Sig. 0.000 }\end{array}$ \\
\hline Risk Taking & 0.612 & $\begin{array}{l}\text { Approx. Chi-Square 18.711 } \\
\text { df 10 } \\
\text { Sig. 0.044 }\end{array}$ \\
\hline Innovativeness & & $\begin{array}{l}\text { Approx. Chi-Square 34.238 } \\
\text { df 6 } \\
\text { Sig. 0.000 }\end{array}$ \\
\hline Firm & 0.698 & $\begin{array}{l}\text { Approx. } \\
\text { Performance }\end{array}$ \\
& & $\begin{array}{l}\text { Chi-Square } \\
\text { df 3 } \\
\text { Sig. } 0.003\end{array}$ \\
\hline
\end{tabular}

Factor analysis was utilized to examine the underlying patterns of relationships among the selected items. In this study as illustrated in Table 2, factor loadings above 0.50 were retained while those with loading less than 0.5 were dropped (Hair et al., 2010). The variability of each observed variable that could be explained by the extracted factors were checked by extracting the communality values. All extracted communalities were found to be greater than 0.5 implying that the variables fitted well with other variables in the factor (Kline, 2007). Principal component analysis varimax rotation was used to extract the factors and the results revealed that 6 extracted factors out of 15 explained $72.5 \%$ of total variance in the data. The six factors in the initial solution had 8 eigen values of 3.047 .

Table 2: Factor Loading Matrix

\begin{tabular}{|l|l|l|l|l|}
\hline Items/constructs & $\begin{array}{l}\text { Firm } \\
\text { Performance }\end{array}$ & Innovativeness & Proactiveness & Risk Taking \\
\hline FP2 & 0.567382 & & & \\
\hline FP3 & 0.953855 & & & \\
\hline IN1 & & 0.823381 & & \\
\hline IN2 & & 0.808083 & & \\
\hline PR2 & & & 0.753226 & 0.665653 \\
\hline PR4 & & & 0.708517 & 0.931032 \\
\hline R1 & & & & \\
\hline R2 & & & & \\
\hline
\end{tabular}

Confirmatory factor analysis (CFA) was performed using SmartPLS version 2.0 software in order to establish the extent to which the observed data validate and fit the pre-specified theoretically based model (Chao \& Spillan, 2010). CFA was estimated on multiple criteria such as construct reliability, convergent validity and discriminant validity as illustrated in Table 3. Construct validity was assessed by computing composite reliability and internal consistency of the items. Composite reliability was evaluated using SmartPLS which generated values above 0.6 which was found to be accepted. Internal consistency was estimated using Cronbach's alpha $(\alpha)$ and the values wereabove 0.600 which is higher than the recommended threshold of 0.500 demonstrating adequate reliability (Hair, Black, Babin\& Anderson, 2010). In this study, convergent validity was assessed using Average Variance Extracted (AVE). The Average Variance extracted (AVE) for risk taking was 0.655 , proactiveness was 0.535 , innovativeness was 0.665 and firm performance was 0.616 which exceeded the cut off value of 0.5, thus confirming convergent validity (Bryman, 2012). To satisfy the requirement of discriminant validity of the measurement model, this study followed the criterion suggested by Fornell and Larcker (1981). The discriminant validity was confirmed as indicated in Table 4 as the square root of a construct's AVE was greater than the correlation between the construct and other constructs in the model (Madhoushi, Sadati\& Delavari, 2011). 
Table 3: Results of Construct and Convergent Validity

\begin{tabular}{|l|l|l|l|}
\hline Construct & $\begin{array}{l}\text { Composite } \\
\text { Reliability } \geq 0.6\end{array}$ & $\begin{array}{l}\text { Cronbach } \\
\text { Alpha } \geq 0.5\end{array}$ & AVE \\
\hline Proactiveness & 0.6965 & 0.645 & 0.535 \\
\hline Risk taking & 0.7869 & 0.514 & 0.655 \\
\hline Innovativeness & 0.7991 & 0.658 & 0.665 \\
\hline Firm Performance & 0.7507 & 0.556 & 0.616 \\
\hline & & & \\
\hline
\end{tabular}

Table 4: Results of Discriminant Validity

\begin{tabular}{|l|l|l|l|l|}
\hline & Firm Performance & Innovativeness & Proactivenss & Risk Taking \\
\hline Firm Performance & 0.7848 & & & \\
\hline Innovativeness & -0.101302 & 0.8158 & & \\
\hline Proactiveness & 0.249599 & -0.111609 & 0.7312 & \\
\hline Risk Taking & 0.243947 & 0.325621 & 0.106454 & 0.8093 \\
\hline
\end{tabular}

\subsection{Structural Model and Hypothesis Testing}

Structural Equation Modelling partial least squares (SEM-PLS) was used for model analysis and hypothesis testing. SEM-PLS was used in the study becauseit provides more flexibility in modeling second order constructs and formative constructs (Chin, 1998). SEM-PLS can also account for measurement errors of latent constructs and assess significance of structural models simultaneously (Byrne, 2001).The structural model was evaluated by examining the $\mathrm{R}^{2}$ values and the size of the structural path coefficient. The stability of the estimates was examined by using the $t$-statistics obtained from a bootstrap test with 500 resamples. The resultant T-tests statistics from the bootstrapping procedure provided the basis for determining which relationships are statistically significant (Hensler, Ringle\& Sinkovics, 2009). The results as illustrated in Figure 1 revealed that the path coefficient between entrepreneurial orientation and firm performance was positive and significant with a path coefficient of 0.536 and a significance level of $0.001 \quad(\beta=0.536, p<0.001)$. The path coefficient implied that for every 1 unit increase in entrepreneurial orientation, firm performance was increased by 0.536 units. The value of $\mathrm{R}^{2}$ coefficient was 0.287 which indicated that $28.7 \%$ of the variation in firm performance can be accounted for by entrepreneurial orientation.

Figure 1: Item Loadings and Path Coefficient

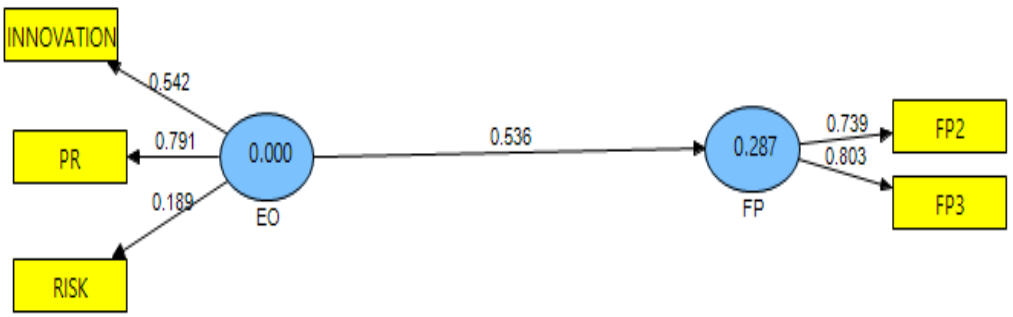

T-statistics was used to test the significance to the relationship between entrepreneurial orientation and firm performance where critical values for t-statistics should be greater than 1.96 at 0.001 levelof significance. The resultant T-tests statistics are illustrated in Figure 2showed that the model was significant at 0.001 significance level for a two tailed test with $\mathrm{t}=7.135$.

Figure 2: T-statistics for entrepreneurial orientation and firm performance

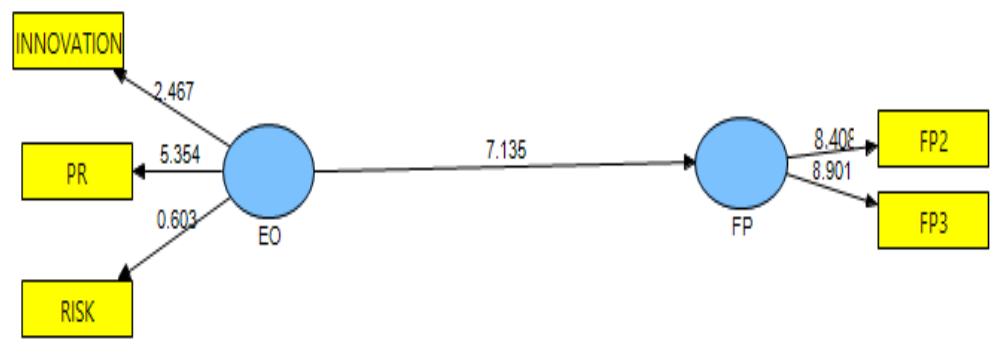


Table 5: Results of Hypothesis Testing

\begin{tabular}{|l|l|l|l|l|l|}
\hline Hypothesis & $\begin{array}{l}\text { Original } \\
\text { Sample }\end{array}$ & $\begin{array}{l}\text { Sample } \\
\text { Mean }\end{array}$ & $\begin{array}{l}\text { Standard } \\
\text { Deviation }\end{array}$ & $\begin{array}{l}\text { Standard } \\
\text { Error }\end{array}$ & $\begin{array}{l}\text { T- } \\
\text { Statistics Decision }\end{array}$ \\
\hline $\begin{array}{l}\text { Entrepreneurial orientation - } \\
\text { > Firm performance }\end{array}$ & 0.536 & 0.556 & 0.075 & 0.075 & 7.135 Supported \\
\hline
\end{tabular}

The results of the hypothesis testing illustrated in Table 5 above indicate that entrepreneurial orientation has a positive and statistically significant relationship with firm performance of Kenya's agro processing SMEs. The results are consistent with the research findings from a study by Al-Swidi and Al-Hosam (2012) which found that entrepreneurial orientation has a significant influence on organizational performance. The point of distinction is that entrepreneurial orientation in this study denotes a higher explanatory power of $28.7 \%$ compared to the study byAl-Swidi and Al-Hosam (2012) which found an explanatory power of $26 \%$. The study results are in agreement with a study by Mahmood and Hanafi (2013) which found that entrepreneurial orientation has a significant relationship with business performance of women-owned SMEs in Malaysia. Similarly, the results concur with a study by Otieno, Bwisa and Kihoro (2012) which found that performance of Kenya's manufacturing firms operating under the East African Community regional integration are significantly influenced by entrepreneurial orientation, in terms of sales, profits and employment.

\section{Summary, Conclusions and Recommendations}

The findings of this study reveal that entrepreneurial orientation as a second-order construct comprised of proactiveness, risk taking and innovativeness has a strong, positive and statistically significant relationship with firm performance of Kenya's agro processing SMEs. Specifically, entrepreneurial orientation has a significant positive effect on firm performance of agro processing SMEs in terms of growth and profitability $(\beta=0.536, p<0.001, t=7.135)$. This is in line with the Resource Based Theory that proposes that sustainable competitive advantage and enhanced firm performance lie primarily in firms that create bundles of tangible and intangible strategic resources that competitors find difficult to substitute or imitate without great efforts.

Based on the findings, it can be concluded that entrepreneurial orientation as a uni-dimensional construct is an important predictor of firm performance of agro processing SMEs, in terms of growth and profitability.A number of managerial implications could be derived from this study. Firstly, owner/managers of these enterprises should consider Entrepreneurial orientation as a vital element for firm performance. Secondly, owner/managers of agro processing SMEs should create an entrepreneurial culture that supports entrepreneurial orientation posture of its employees. It is only when employees of agro processing SMEs engage in productmarket innovations, undertake somewhat risky ventures and are first to come up with proactive actions that these firms will enhance firm performance. This study recommends that agro processing industries should adopt an entrepreneurial orientation that leads to enhanced firm performance.

\subsection{Suggestions for Further Research}

The present study has a number of limitations that need to be addressed in further research studies. First, the study focused on agro processing SMEs in Kenya which affects generalization of the study findings to other industries and regions. There is need for more context specific research in developing countries before establishing a general theory on the relationship between entrepreneurial orientation and firm performance. Second, due to the difficulty experienced in getting financial performance measures of agro processing SMEs in Kenya, this study relied solely on subjective measures of firm performance. There is a need for further studies to use objective indicators of financial measures or non-financial measures of firm performance. Third, the study of entrepreneurial orientation concentrated on three dimensions namely proactiveness, risk taking and innovativeness. Further research may be needed to study all five dimensions of entrepreneurial orientation namely proactiveness, risk taking, innovativeness, competitive aggressiveness and autonomy.

\section{Acknowledgement}

I wish to express my gratitude to my supervisors, Prof. Robert Gichira and Dr. Kenneth Wanjau, for their professionalism, availability and patience in guiding me through the study. Without your invaluable professional guidance and support, this study would not have come to fruition.I also wish to thank my loving husband Samuel Wambugu, our children Andrew, Joshua and Channah for their support, encouragement, prayers and understanding.

\section{References}

[1]. Aggarwal, N.,\& Gupta, M. (2006). Market performance measures: Current status in Indian companies. Decision, 33(1), 47-74.

[2]. Al-Swidi, A. K.,\& Al-Hosam, A (2012). The effect of entrepreneurial orientation on the organizational performance: A study on the Islamic banks in Yemen using the partial least squares approach. Arabian Journal of Business \& Management Review (Oman Chapter), 2(1), 73-84. 
[3]. Awang, A., Ahmad, Z, A., Asghar, A.R., Subari, K.A.,\& Kassim, S. A. (2011). Firm entrepreneurial orientation and knowledge/networking of agro based enterprises in Malaysia: The role of technology and strategy. African Journal of Business Management, 5 (22), 9685-9706.

[4]. Bordens, K. S.,\& Abbott, B. B. (2014). Research design and methods: A process approach (9th ed.). San Francisco: McGraw Hill.

[5]. Byrne, B. M. (2001). Structural equation modeling with AMOS: Basic concepts, applications, \& programming. Mahwah, NJ: Lawrence Erlbaum Associates, Inc.

[6]. Bryman, A. (2012). Social Research Methods, (4th ed). New York: Oxford University Press.

[7]. Bryman, A., \& Bell, E. (2011).Business Research Methods, (3rd ed). New York: Oxford University Press.

[8]. Chao, M.C.,\& Spillan, J.E. (2010). The journey from market orientation to firm performance. A comparative study of US and Taiwanese SMEs.Management Research Review, 33(5), 472-483.

[9]. Cooper, R. D.,\& Schindler, S.P. (2011).Business Research Methods, (10 $0^{\text {th }}$ ed.). New York:Mc Graw Hill.

[10]. Covin, J. G., \& Slevin, D. P. (1986). The development and testing of an organizational-levelentrepreneurship scale in Ronstadt, R., Hornaday, J.A., Peterson, R.\& Vesper, K.H. (Eds). Frontiers of Entrepreneurship Research. Wellesley: Babson College.

[11]. Covin, J. G.,\& Slevin, D. P. (1988). The influence of organization structure on the utility of an entrepreneurial top management style. Journal of Management Studies, 25, 217-234.

[12]. Covin, J. G.,\& Slevin, D. P. (1989). Strategic management of small firms in hostile and benign environments. Strategic Management Journal, 10(1), 75-87.

[13]. Covin, J. G., \& Slevin, D. P.(1991). A conceptual model of entrepreneurship as firm behavior.Entrepreneurship Theory and Practice, 16(1), 7-25.

[14]. Covin, J., Green, K. M.,\& Slevin, D. P. (2006). Strategic process effects on the entrepreneurial orientation-sales growth rate relationships. Entrepreneurship: Theory\& Practice, 30(1), 57-81.

[15]. Cunningham, L. X.,\& Rowley, C. (2007).Human resource management in Chinese small and medium enterprises. Personnel Review, 36(3), 415-439.

[16]. Da Silva, C.A., Baker, D., Shepherd, A.W., Jenane, C.,\& Miranda-da-Cruz,S.(2009). Agro - industries for Development. Wallingford, United Kingdom: CABI Publishing.

[17]. Dess, G. G., \& Lumpkin, G.T. (2005). The role of entrepreneurial orientation in stimulatingeffective corporate entrepreneurship. Academy of Management Executive, 19(1), 147-156.

[18]. Fairoz, F.M., Hirobumi, T.,\& Tanaka, Y. (2010). Entrepreneurial orientation \& performance of small \& medium enterprises of Hambantoa District, Sri Lanka. Asian Social Science, 6(3), 34- 47.

[19]. Fornell, C.,\& Larcker, D. F. (1981). Evaluating structural equation models with unobservable variables \& measurement error. Journal of Market Research, 18(1), 39-50.

[20]. Hair, J. F., Black, W. C., Babin, B. J.,\&\&erson, R. E. (2010). Multivariate Data Analysis. A Global Perspective. (7 ${ }^{\text {th }}$ ed.) Upper Saddle River, Boston: Pearson Education lnc.

[21]. Henseler J., Ringle, C. M.,\& Sinkovics, R. R. (2009). The Use of Partial Least Squares Path Modeling in International Market. Advances in International Market, 20, 277-319.

[22]. Idar, R., \& Mahmood, R. (2011). Entrepreneurial \& market orientation relationship to performance: The SME Perspective. Interdisciplinary Review of Economics and Management, 1(2), 1-24.

[23]. Kaiser, H.E. (1974). An index of factorial simplicity. Psychometrika, 39, 31-36

[24]. Kaplan, R. S., Norton, D. P. (2004). Strategy Maps: Converting intangible assets into tangible outcomes. Harvard Business School Press: Boston Massachusetts.

[25]. Keh, H. T., Nguyen, T. T.,\& Ng, H. P. (2007).The effects of entrepreneurial orientation and market information on the performance of SMEs. Journal of Business Venturing, 22(4), 592-611.

[26]. Kenya Association of Manufacturers (2010). Kenya Association of manufacturers' directory. Nairobi: Kenya Association of Manufacturers.

[27]. Kenya National Bureau of Statistics. (2013). Economic Survey. Nairobi: Government Printer.

[28]. Kline, R, B. (2005). Principles and Practice of Structural Equation Modeling. New York: Guilford Press

[29]. Kormawa, P.M., Wohlmuth, K.,\& Devlin, J. (2011). Agribusiness for Africa's prosperity: Country case studies. Working Paper. ( $2^{\text {nd }}$ Ed.). Vienna: UNIDO.

[30]. Kreiser, P., Marino, L.,\& Weaver, K. (2002).Assessing the psychometric properties of the entrepreneurial orientation scale: A multi-country analysis. Entrepreneurship Theory \& Practice, 26(4), 71-95.

[31]. Li, Y. H., Huang, J.W., \& Tsai, M.T. (2009).Entrepreneurial orientation and firm performance: the role of knowledge creation process. Industrial Market Management, 38, 440-449.

[32]. Lumpkin, G.T., \& Dess, G.G. (1996). Clarifying the entrepreneurial construct \& linking it to performance. Academy of Management Review, 21(1), 135-172.

[33]. Lumpkin, G.T.,\& Dess, G.G. (2001). Linking two dimensions of entrepreneurial orientation tofirm performance: the moderating role of environment \& industry life cycle. Journal ofBusiness Venturing, 16, 429-451.

[34]. Lyon, D., Lumpkin, G.,\& Dess, G. (2000).Enhancing entrepreneurial orientation research: Operationalising \& measuring a key strategic decision making process. Journal of Management, (26)5, 1055-1085.

[35]. Madhoushi, M., Sadati, A.,\& Delavari, H. (2011). Entrepreneurial orientation \& innovation performance: The mediating role of knowledge management. Asian Journal of Business Management, 3(4), 310 - 316.

[36]. Miller, D.,\& Friesen, P. H. (1984).Organizations: A Quantum View, Englewood Cliffs, New Jersey: Prentice-Hall.

[37]. Morris, M. H., Kuratko, D. F.,\& Covin, J. G. (2008).Corporate Entrepreneurship\& Innovation, ( ${ }^{\text {nd }}$ ed). Mason: Thomson Higher Education.

[38]. Mugenda, A. G. (2008). Social Sciences Research: Conception, Methodology \& Analysis, Nairobi: Kenya Applied Research \& Training Services.

[39]. Otieno, S., Bwisa, H.M.,\& Kihoro, J. M. (2012).Influence of entrepreneurial orientation on Kenya's manufacturing firms operating under East African regional integration. International Journal of Learning\& Development, 2(1), 299 - 320.

[40]. Rauch, A., Wiklund, J., Lumpkin, G.T.,\& Frese, M. (2005). Entrepreneurial orientation \& firm performance: An assessment of past research \& suggestions for the future. Entrepreneurship Theory \& Practice, 19(7), 12-18.

[41]. Republic of Kenya. (2007). Kenya -Vision 2030, A Globally Competitive and Prosperous Kenya. Nairobi: Government Printer.

[42]. Republic of Kenya. (2008). Master Plan Study for Kenya Industrial Development Final Report 2. Nairobi: Government Printer.

[43]. Republic of Kenya. (2012). Statistical Abstract. Nairobi: Kenya National Bureau of Statistics.

[44]. Republic of Kenya. (2013). Economic Survey. Nairobi: Government Printer. 
[45]. Stevenson, H. H., \& Jarillo-Mossi, J.C. (1990). A paradigm of entrepreneurship: Entrepreneurial management. Strategic Management Journal, 11(2), 17-27.

[46]. Singh, R. K., Garg, S. K., \& Deshmukh, S. G. (2008). Strategy development by SMEs for competitiveness: a review. Benchmark: An International Journal, 15(5), 525-547.

[47]. Tajeddini, K. (2010). Effect of customer orientation and entrepreneurial orientation on innovativeness: Evidence from the hotel industry in Switzerland. Tourism Management, 31(2), $221-231$.

[48]. Venkatraman, N. (1989). Strategic orientation of business enterprises: the construct, dimensionality and measurement. Management Science, 35(8), 942-962.

[49]. Wang, Y.,\& Poutziouris, P. (2010). Entrepreneurial risk taking: empirical evidence from UK family firms. Entrepreneurial Behavior\& Research, 16(5), 370- 388.

[50]. Wiklund, J. (1999). The sustainability of the entrepreneurial orientation - performance relationship. Entrepreneurship Theory\& Practice, 24(1), 37-48.

[51]. Wiklund, J.,\& Shepherd, D. (2003).Knowledge-based resources, entrepreneurial orientation, \& the performance of small \& medium sized business. Strategic Management Journal, 24 (13), 1307-1314. http://dx.doi.org/ 10.1002/smj.36.

[52]. Wiklund, J.,\& Shepherd, D. (2005). Entrepreneurial orientation and small firm performance: a configurational approach. Journal of Business Venturing, 20, 71-91.

[53]. Zainol, F.A.,\& Ayadurai, S. (2011). Entrepreneurial orientation and firm performance: The role of personality traits in Malay family firms in Malaysia. International Journal of Business \& Social Sciences, 2(1), $59-71$. 